\title{
Kant, Bergson, and Iqbal on the Concept of Time and its Effect on Iqbal's Reconstruction of Freewill
}

Kant, Bergson ve İkbal'de Zaman Kavramı ve Bunun İkbal'de Özgür İradenin Yeniden İnşasına Etkisi

\section{Baki KARAKAYA Asiye Şefika Sümeyye KAPUSUZ}

PhD Student, Istanbul University, Philosophy Department, Istanbul/Türkiye

bakikarakaya19@gmail.com | orcid.org/0000-0002-7130-

$\underline{5763}$ | ror.org/3a5qrr21

Contribution Percentage: \%50
MA Student, Marmara University, Department of Basic Islamic Studies, Istanbul/Türkiye

sumeyyekapusuz@gmail.com |orcid.org/0000-00028629-4630 | ror.org/02kswqa67

Contribution Percentage: \%50

\section{Article Information \\ Article Type \\ Research Article \\ Date Recieved \\ 15 September 2021 \\ Date Accepted \\ 29 December 2021 \\ Date Published \\ 31 December 2021 \\ Plagiarism}

This article has been scanned with iTenticate software.

\section{No plagiarism detected.}

Ethical Statement

It is declared that scientific and ethical principles have been followed while carrying out and writing this study and that all the sources used have been properly cited

(Baki Karakaya - Asiye Şefika Sümeyye Kapusuz).

Licensed under CC BY-NC-ND 4.0 license.

Cite As 


\begin{abstract}
Philosophy should be understood with its accumulative structure. Thus, when one strives to understand a philosopher's thoughts, he/she should not isolate the philosopher from the previous and contemporary theories in his/her era; and should take into account this accumulative and continuous structure. In this context, Kant's, Bergson's, and Iqbal's understandings of time seem to have continuity in themselves, even if they might be seen as having incompatible points. Kant's understanding of time can be considered in two periods as pre-Critical and Critical. In the former, Kant accepts the own-reality and existence of time itself, outside of the human mind. But he also sows the seed of an understanding of time as a prior intuition to all sensations, while he is still in his pre-critical period. Hence, his focus seems to have shifted to a subject-centred approach. In his critical period, subject-centrality becomes more obvious and Kant claims that time is prior to any externality. According to him, time locates things in simultaneity and succession for the perception of mind as a sensible intuition. Bergson, on the other hand, clearly exploits Kant, even though he criticizes Kant in many aspects. Bergson's understanding of time is comprised of two components: Pure duration and homogenous time. Pure duration is affected by the Kantian conception of time in the sense of being subject-centred. It is the time that each consciousness has individually as a combination of one's past and present in a whole; and it is, in its essence, heterogeneous, unorderly successive, and indivisible. Homogenous time has its roots, again, in Kant's thoughts in the sense of being serial and simultaneous. It is the impersonal common ground for individuals on which pure durations can work in a harmony. When it comes to Iqbal, he benefits from both Kant's time as a form of sensible intuition and Bergson's pure duration. Iqbal, by using both of these concepts of time, reconstructs the Divine Time in Islamic thought, and thus, freewill. By means of pure duration and creativity, mechanical understanding of the universe is refused by Bergson and Iqbal. By doing so, Iqbal allows freewill to permeate through pure duration of the God, namely the Divine Time, and to penetrate into pure durations of all egos. Throughout this article, we mainly intend to retrace Iqbal's reconstruction of freewill by having use of the concept of pure duration, and the Divine Time as pure duration of the God.
\end{abstract}

Keywords: Kalām, Philosophy, Time, Duration, Iqbal, Bergson, Kant.

\title{
Öz
}

Felsefe, kümülatif yapısı ile ele alınmalıdır. Bu yüzden, bir filozofun düşünceleri anlaşılmak istendiğinde, o kendi çağındaki mevcut ve geçmiş teorilerden soyutlanmamalı ve bu kümülatif ve devamlılık arz eden yapı dikkate alınarak incelenmelidir. Bu bağlamda, Kant, Bergson ve İkbal'in zaman anlayışları, bazı uyumsuz noktalara sahip gibi anlaşılabilseler de, dikkatle incelendiğinde birbirleri arasında bir devamlılı̆̆ın bulunduğu göze çarpar. Kant'ın zaman anlayışı, Kritik öncesi ve Kritik dönemi olmak üzere iki dönemde incelenebilir. Kritik öncesi döneminde Kant, zamanın insan zihninin dışında kendinde bir gerçekliğe ve varlığa sahip olduğunu kabul eder. Fakat Kant, zamanı bütün duyuları önceleyen bir görü olarak anlamasının tohumlarını da hala Kritik öncesi dönemde iken eker. Bu doğrultuda, onun odağı özneyi merkeze alan bir tutuma doğru ilerler görünür. Kritik döneminde özne merkezci konumu daha da belirginleşir ve Kant, zamanın bütün dışsallıkları öncelediğini iddia eder. Ona göre zaman, duyulur bir görü olarak, eşyayı zihnin algılayabilmesi için eşzamanlılık ve ardışıklık içinde konumlandırır. Diğer taraftan Bergson, Kant'ı pek çok açıdan eleştirmekle beraber onun düşüncelerinden açık bir şekilde faydalanır. Bergson'un zaman anlayışı iki bileşenden oluşur: Salt süre ve homojen zaman. Salt süre, özne-merkezci olması bakımından üzerinde Kant'in düşünce pratiğinin etkisinin görünür olduğu bir kavramsallaştırmadır. Bu, her bir bilincin, kişinin geçmiş ve şimdisini bir bütünde birleştirerek bireysel olarak sahip olduğu ve özünde heterojen, sırasız bir şekilde ardışık ve bölünemez zamandır. Homojen zaman ise sıralı ve eşzamanlı olması bakımından köklerini yine Kant’ta bulur. Homojen zaman, salt sürelerin uyum içinde çalışmasını sağlayan, bireyler için ortak zemini teşkil eden zamandır. Bu iki filozofun düşünceleri doğrultusunda İkbal'in zaman teorisi incelendiğinde, onun hem duyulabilir görünün bir formu olan Kant'ın zamanından hem de Bergson'un salt süresinden faydalandığı ortaya çıkar. İkbal, bu iki zaman anlayışını kullanarak İslam düşüncesinde İlahi Zaman'ı ve dolayısıyla da özgür iradeyi yeniden inşa eder. Salt süre ve yaratıcılık açısından, evrene yönelik mekanik bir anlayış Bergson ve İkbal tarafından reddedilir. Böylece İkbal, özgür iradenin Tanrı'nın salt süresi, yani İlahi Zaman, aracılığı ile yayılmasına ve tüm benliklere ait salt sürelere nüfuz etmesine izin verir. Biz, bu makale aracılığı ile, İkbal'in salt süre mefhumunu ve Tanrı'ya ait salt süre olarak İlahi Zaman'ı kullanarak özgür irade anlayışını yeniden inşa etmesinin köklerine gitmek niyetindeyiz.

Anahtar Kelimeler: Kelam, Felsefe, Zaman, Süre, ỉkbal, Bergson, Kant. 


\section{Introduction}

The concept of time has been taken as a basis to justify different reflections in philosophy. In our case, it is the main basis and anchor, or reference point, upon which freewill is built. Iqbal's reconstruction of freewill and its roots are going to be analysed in this article. Iqbal's reconstruction of freewill relatively has potential to have a transformative effect on Islamic thought, and is an original and inclusive modern theorisation. Thus, his concept of freewill and the background of this concept should be researched. By doing so, the concept of time and its adventure from Kant's to Iqbal's views cannot be excluded due to that this concept is the main component of Iqbal's concept of freewill, and that his concept of freewill is directly related to his understanding of time, and thus, to Kant's and Bergson's views of time. The elaboration and elucidation of the concept of time represents the main structure of this article. Nevertheless, Iqbal's concept of freewill as the implication of his concept of time should be seen as the peak point. In this context, we are going to focus on the concept of time and its adventure from Kant's to Iqbal's views by passing through Bergson's understanding of it. Then, we are, at the end of the article, going to strive to unveil the effect of the concept of time on Iqbal's reconstruction of freewill.

Iqbal's philosophy has been investigated by numerous researchers. Only some of these investigations have focused on Iqbal's concepts of time and freewill. However, those investigations do either not apparently mention the roots of his understanding of time or slightly speak of them, and overlook the very intelligible relation between his concepts of time and freewill or between his predecessors' and his understandings of time. Especially they have made connections either between Kant and Iqbal regarding their compatible and incompatible epistemological views by excluding Bergson, or between Bergson and Iqbal in terms of their conceptualisations of time by setting aside Kant's concept of time. ${ }^{1}$ Thus, it seems to lack a continual line from Kant to Iqbal in regard to their approaches to the concept of time, even if they have irrefutably incompatible points, and requires the relation between Iqbal's concepts of time and freewill as the final outcome of this line. These attempts are obviously undetailed and inadequate to understand Iqbal's views of time and freewill, and the roots of them. Through this article, we aim at highlighting that line, which has been ignored for a long time, by focusing on the roots of Iqbal's concept of time, and at making a connection between his concepts of time and freewill.

\footnotetext{
For more details, see P. T. Raju, Idealistic Thought of India (London: George Allen \& Unwin, 1953), 382-394; Carimo Mohomed, "Towards a Final Combination - Muhammad Iqbal's Philosophy of History", Journal of Philosophy and Ethics 2/1 (2020), 20-24; Carimo Mohomed, "Towards a Final Combination: Muhammad Iqbal's Philosophy of History", Waikato Islamic Studies Review 6/2 (2020), 25-33; Riffat Hassan, The Main Philosophical Idea in the Writings of Muhammad Iqbal (1877-1938) (Durham: Durham University, Doctoral Thesis, 1968), 143-168; Riffat Hassan, "The Meaning and Role of Intuition in Iqbal's Philosophy", Iqbal Review 26/1 (1985), 67-99; Stephan Popp, "Muhammad Iqbal - Reconstructing Islam along Occidental Lines of Thought", Interdisciplinary Journal for Religion and Transformation in Contemporary Society 5/ (2019), 201-229; Richard S. Wheeler, "The Individual and Action in the Thought of Iqbal", The Muslim World 52/3 (1962), 197-206; Souleymane Bachir Diagne, "Bergson in the Colony: Intuition and Duration in the Thought of Senghor and Iqbal", Qui Parle 17/1 (2008), 125-145; Carimo Mohomed, "'The Days of God"- Muhammad Iqbal's Conception of Time and History", Journal of Islamic Thought and Civilization 7/ (2017), 1-17.
} 
The concept of time has been investigated in terms of its relation to both universe and the concept of space. With the emergence of the concept of subject being able to establish itself primarily, the possession of the concept of time passed to it and was adopted by human species. This does not mean that all approaches to the concept of time have been gathered under the concept of subject. Nevertheless, particularly after Kant's (d. 1804) intervention by means of his Critique of Pure Reason, time has in part been discussed as a property of the subject, and, thus, as that of human being. Hereby, as this has apparently been the case, it should be stated that Kant's understanding of time and space might not be the same with his predecessors' approaches to it. This differentiation basically refers to that objective and external reality of time was annihilated and slaughtered by Kant. As an instance to this aspect, we might prove that

"Newton assumes that space and time 'subsist', while Leibniz assumes that space and time 'inhere', but both suppose that space and time have objective reality independent of any transcendental cognitive conditions. As such both of their accounts, according to Kant, face an irresolvable conflict". ${ }^{2}$

And it can also be claimed that Kant's understanding of time should be understood as it is differentiated from Locke's view of time deriving from sense and reflection. ${ }^{3}$ In this sense, the concept of time does not arise from, or come out of, senses, but is necessarily presupposed by them. Thus, Kant's view of time and space should be realised as an enthusiasm to reconcile subject and external world, as an enthusiasm lacking the possibility of the external, or noumenal, to be knowable, even if it is thinkable.

Nevertheless, Kant's spurt, to say the least, had an enormous effect on his successors. Even though Bergson (d. 1941) and Iqbal (d. 1938) criticise his view of time in regard to its deprivation of freewill, and, thus, its risky speculation to demolish the individuality of subject, they have use of Kant's understanding of time to construct their freedom-based thought systems grounded on the intuition as a method and pure duration as the indication of the state of consciousness.

Bergson clearly divides time into two branches. The first one is the pure duration, as the essential component of individual time, heterogeneous, unorderly successive, and indivisible. The second one is, as it is obvious, homogeneous time, as the external time, which is measurable, simultaneous, and divisible, and, at the same time, which does constitute the possibility of commonalities of pure durations of all individual consciousnesses. By doing so, Bergson seems to assert both that freedom is possible through pure duration, and that all consciousnesses are bonded to each other through impersonal and homogeneous time as to be space.

On the other hand, Iqbal seems to intend building his system of thought, which does include his understanding of God, on Bergson's understanding of pure duration. His understanding of the universe consists of a dynamic and organic totality of it and against mechanism. Thus, he basically asserts all egos and the Ultimate Ego as having freewill encompassing that of the latter which exhibits an ultimate instance of Freewill by giving up His absolute power to allow other egos to have freewill. Iqbal, thus, adopts two kinds of time which are serial time similar to Bergson's

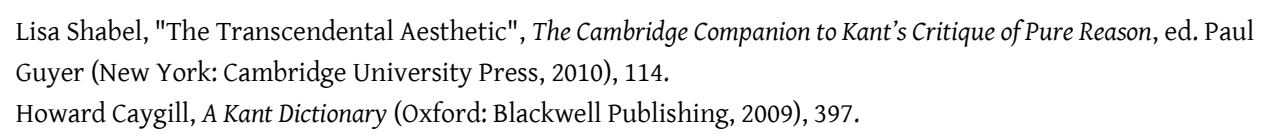


homogeneous time, and pure duration resembling Bergson's pure duration. And, as to be bonded to his understanding of time, he propounds two selves unfolding themselves through the function of time, i.e., efficient self tied to serial time, and appreciative self tied to pure duration, that is, his conceptualisation of selves also resembles that of Bergson's selves. However, Iqbal's understanding of pure duration, in addition to that of Bergson, includes teleology and future. Besides, this differentiation of Iqbal's pure duration from that of Bergson is reflected to bifurcation of the concept of duration. Thus, Iqbal's concept of duration might be divided into two types of it, that of egos, and of Ultimate Ego. On the other hand, it will be seen that Iqbal takes his serial time from Kant's understanding of time. Hence, he grounds his theory of Divine Time, freewill and destiny on, to a great extent, Bergson's approach to time, and, on Kant's understanding of time.

The reason for writing this article lies down beneath the necessity to show the background of Iqbal's understanding of time, which plays a central role in his understanding of universe, that is, one of the rare contemporary interpretations of modern science and philosophy with an Islamic stand, and to establish a continuity between the systems of thought in different times and from different cultures. Beside contributing to found a continuity in systems of thought, we, on the other hand, intend to emphasise the gaps between these philosophers' understanding of time by means of which differences in their approaches to human being as a subject, and as a freewill holder, might indirectly be unveiled. Kant's and Bergson's views on time are reinterpreted by Iqbal and aligned with the Islamic conceptualisation of God. However, our focus is throughout the article going to remain on Kant's and Bergson's views on time and its reinterpretation and reception by Iqbal to re-found the possibility of freewill in Islamic thought.

Our specific reason for starting this article with Kant's view on the issue is his formative thoughts influencing the direction of modern philosophy and driving modern human to an aporia with regard to his/her actions. His one-sided understanding of time is drastically criticised by Bergson and Iqbal. However, at the same time, it is seen to be a basis in the process of founding a new subject. The gradual transformation of the understanding of time becomes visible at this point. Bergson contributes to it by diversify the concept of time, while Iqbal reconciles it with Islamic thought. By doing so, he serves for the regeneration of Islamic thought and paves the way to increase and modernise the power of Islam. Reflecting upon his motivation and background of this manoeuvre through the concept of time and freewill is the absolute point of this article.

To do what we have exhibit above, we will first focus on Kant's understanding of time, then, Bergson's approach to time and to Kant's view of time, and, lastly, we intend to explicate what Iqbal extracts from these different approaches to time, and how Iqbal operates it to reach to peak of freewill in Islamic thought and to the Ultimate Ego.

\section{Kant's Understanding of the Concept of Time}

In Kant's system of philosophy, we are witnesses to the conceptual involvement and reversal of time. In this sense, we are going to emphasise some crucial points about time in Kant's thought. By doing so, we exactly intend to pave the way for showing that Kant's and Bergson's 
understandings of time differ from each other from time to time. In this context, we clearly aim to investigate the approach of Kant to time in depth and then to move to that of Bergson.

While we are focusing thoroughly on Kant's approach to time, we have to make a separation between pre-Critical and Critical period of his thought. As a result, what we need to remark is obviously nothing other than making the difference between these two periods unveiled. However, pre-Critical period should be considered as the establishment phase of his understanding of time, even if his later thought is found to be quite differentiated from the earlier one.

\subsection{Kant's Pre-Critical Thought of Time}

Time, as it is mentioned by Kant in his pre-Critical period, has to have a beginning. Nevertheless, it presents us an infinitude regarding the end of it. According to this approach, time should be realised as a parte post meaning eternity without limits in the future, that is, there will be no end in this kind of time. In this context, we tend to think that Kant, in his pre-Critical period, has unavoidably fallen into the absolute reality of time. At the same time, it is also crucial to denote that Kant thoroughly highlights the process of creation. As he puts it,

\footnotetext{
"the infinity of the future temporal succession, for which eternity is inexhaustible, will thoroughly activate all the spaces of God's presence and gradually set it into rule-bound regularity, appropriate to the excellence of its design. And if, in a daring picture, we could, so to speak, sum up all eternity in a single idea, then we would be able to see the entire infinite space filled with world systems and a completed creation. However, because, in fact, the temporal sequence of eternity the part to come is always infinite and the part gone by is finite, the sphere of developed nature is always only an infinitely small part of the being which has in it the seeds of future worlds and strives to develop itself out of the raw condition of chaos in long or short periods of time. Creation is never complete. True, it once began, but it will never cease". ${ }^{4}$
}

Thus, in his pre-Critical period, Kant admits that the concept of time is independent or free from subject and basically rooted in its own infinite cosmological reality. In addition to this, his concept of time assumes the reality of motion and that of space with regard to Newtonian physics.

On the other hand, Kant's shift from Newtonian point of view to a more specific and genuine system of philosophy is mainly shaped by his texts Concerning the Ultimate Ground of the Differentiation of Directions in Space released in 1768 and On the Form and Principles of the Sensible and the Intelligible World written in 1770. In the former, Kant claims that determination of corporeal form has to be accompanied by a reference to universal absolute space. This means that Kant basically continues to defend Newtonian viewpoint against Leibniz's vantage point by which, in philosophy, things are purely thought, and space is genuinely thrown into the fire of having no reality in itself. Kant conceives the space as it to be endowed to have its own reality, like time having that. He does, in the former released in 1768 , strive to show that 'the ground of the complete determination of a corporeal form does not depend simply on relation and position of its parts to each other; it also depends on the reference of that physical form to universal absolute

Immanuel Kant, Universal Natural History and Theory of the Heavens, trans. Ian Johnston (Arlington: Richer Resources Publication, 2008), 107. 
space. ${ }^{5}$ What is remarkable at this point is obviously nothing other than the reality of space in terms of having its own reality, and that of time. Thus, Kant refuses Leibnizian understanding of space as having no reality in itself and as being constituted by togetherness of things. Rather than Leibnizian approach, Kant asserts that space has its own existence as well as time. Nevertheless, on the other hand, this can be also conceived to be the differentiation of Kant's own thought by conceiving this text as the article in which intuition as a conceptualisation, and a form of sensibility, tenuously and subtly comes into appearance. In this context, as Gözkân clearly puts it, properties of something cannot totally be known without focusing on its relations to space, and, the representation of space makes us to be able to determine the properties of matter. ${ }^{6}$ And, for us, time can also be considered as a part of this inference unveiling the space as a form of sensible intuition. As a result, this text should be understood as Kant's shift from the defence of time and space having their own reality to the line in which it seems to turn out to be located between pure reality of externality and utter imprisonment of time in thought. Thus, it is quite important to realise that Kant, in this text, withdraws the external reality of time and space; however, this does not mean that he ascribes space and time to pure thought or conceptual thought. Rather than both of these approaches, he puts time and space in between by setting out a condition of sensible intuition pertaining neither to external reality nor to pure thought. By so doing, he puts some distance between Leibniz's and his systems. On the other hand, even if it seems to be subtle in this article, he does, to some extent, distinguish his thought of space and time from that of Newton by withdrawing space and time from empirical realm.

Finally, in his text written in 1770, Kant explicitly propounds the concept of time as a form taken under the laws of intuition by which we have our access to the phenomenal world. According to Kant, ' 'the idea of time is an intuition'. ${ }^{8}$ And since, insofar as it is the condition of the relations to be found in sensible things, it is conceived prior to any sensation; it is not a sensory but a pure intuition.' As a result, he conceives of time both to be prior to sensation which necessarily presupposing it, and to be a property of the subject. Time, in this sense, turns out to be an internal component of intuition, and its externality is directly refused by Kant. At the same time, he asserts that

"time is not something objective and real, nor is it a substance, nor an accident, nor a relation. Time is rather the subjective condition, which is necessary, in virtue of the nature of the human mind, for the co-ordinating of all sensible things in accordance with a fixed law. It is a pure intuition". 9

That which is expounded here by Kant is nothing but the imprisonment of time in subject's intuition. According to Heimsoeth, time and space in Kant's novel thought are not principles of

5 Immanuel Kant, "Concerning the Ultimate Ground of the Differentiation of Directions in Space," trans. David Walford - Ralf Meerbote, Theoretical Philosophy, 1755-1770 (New York: Cambridge University Press, 1992), 369. H. Bülent Gözkan, Kant'in Şemsiyesi - Kant'in Teorik Felsefesi Üzerine Yazılar (Istanbul: Yapı Kredi Yayınları, 2018), 82. Immanuel Kant, "On the Form and Principles of the Sensible and the Intelligible World [Inaugural Dissertation]", trans. David Walford - Ralf Meerbote, Theoretical Philosophy, 1755-1770 (New York: Cambridge University Press, 1992), 392.

$8 \quad$ Emphasised by Kant. Unless it is indicated to be emphasised by us, all italics in citations pertains to the author of the text from which it is cited.

$9 \quad$ Kant, "On the Form and Principles of the Sensible and the Intelligible World [Inaugural Dissertation]", 393. 
being, rather than this, they are merely the forms dependent to our sensibility. ${ }^{10}$ Time, in this context, is neither in itself, nor is it based on external world; rather, it is only a condition of form of sensible intuition rooted in human beings. By doing so, Kant's concept of time has gradually been switched to the form of pure intuition of sensibility. In other words, the concept of time in Kant's thought has led to 'a formal whole which is not a part of another whole', to the phenomenal world. ${ }^{11}$

\subsection{Kant's View of Time in his Critical Period}

We have already focused on the shift of Kant's concept of time from objective reality to subjective condition which is necessary for human mind to have representations of objects in intuition. Now, we should strictly focus on Critique of Pure Reason to elaborate Kant's idea of time as a subjective formal condition of sensibility.

According to Kant, time is 'not an empirical concept that is somehow drawn from an experience. For simultaneity and succession would not themselves come into perception if the representation of time did not ground the a priori'. ${ }^{12}$ The concept of time, in this sense, loses its external and objective reality, and is totally withdrawn by Kant to the limits of human mind, or, better to say, to sensible intuition of human beings. He, as he indicates in his earlier text Inaugural Dissertation, explicitly classifies the defenders of objective reality of time in two categories. As he puts it,

\footnotetext{
"those who assert the objective reality of time either conceive of time as some continuous flux within existence, and yet independently of any existent thing (a most absurd fabrication) - this is a view maintained, in particular, by the English philosophers - or else they conceive of it as something real which has been abstracted from the succession of internal states - the view maintained by Leibniz and his followers". ${ }^{13}$
}

He does not even pay attention to the former, and, as we see, calls it 'a most absurd fabrication'. However, the latter, namely Leibniz's understanding of time, obliges Kant much more than the first one to reply to its approach assuming time to be objective, and rejecting it to be the subjective condition of sensible intuition. Kant rigorously criticises the latter as follows, Leibniz's objective reality of time
"completely neglects simultaneity, the most important corollary of time. It, thus, throws into confusion all use of sound reason, for, rather requiring that the laws of motion should be determined by reference to the measure of time, it demands that time itself should be determined, in respect of its own nature, by reference to things which are observed to be in motion or in any series of internal changes." ${ }^{14}$

Thus, Kant accordingly takes the concept of time as determinative, rather than conceiving of it as determined by motion. The reason why time is prior to motion or any externality, according to Kant, is its power to determine specific positioning of things in simultaneity or succession. At the

\footnotetext{
Heinz Heimsoeth, Kant'in Felsefesi, trans. Takiyettin Mengüşoğlu (Ankara: Doğu Batı Yayınları, 2012), 60-61. Kant, "On the Form and Principles of the Sensible and the Intelligible World [Inaugural Dissertation]", 395. Immanuel Kant, Critique of Pure Reason, trans. Paul Guyer - Allen W. Wood (New York: Cambridge University Press, 1998), 178.

$13 \quad$ Kant, "On the Form and Principles of the Sensible and the Intelligible World [Inaugural Dissertation]", 394.

$14 \quad$ Kant, "On the Form and Principles of the Sensible and the Intelligible World [Inaugural Dissertation]", 394.
} 
same time, Leibnizian understanding of time certainly lacks simultaneity by ignoring the state in which motion could not be found. In other words, this kind of understanding of time criticised by Kant encompasses merely succession, or better, liquidity of time in which it is, indeed, impossible to find moment as the time span in which things are standing together. As a consequence of his earlier objection to Leibnizian understanding of time, Kant propounds time as a priori grounding form of intuition. With the assistance of time as a form of sensible intuition, simultaneity and succession come into perception. Furthermore, according to Kant,

\footnotetext{
"time is a necessary representation that grounds all intuitions. In regard to appearances in general one cannot remove time, though one can very well take the appearances away from time. Time is therefore given a priori. ...time itself (as the universal condition of their possibility) cannot be removed". ${ }^{15}$
}

Thus, as we have thoroughly noticed, Kant, in his first Critique, definitely employs time as the universal condition of both intuition and experience. What it means is that, although time is subjective condition of sensible intuition, it rather has objective validity. It cannot differently be discovered and does not depend on each individual. According to Holzhey and Mudroch,

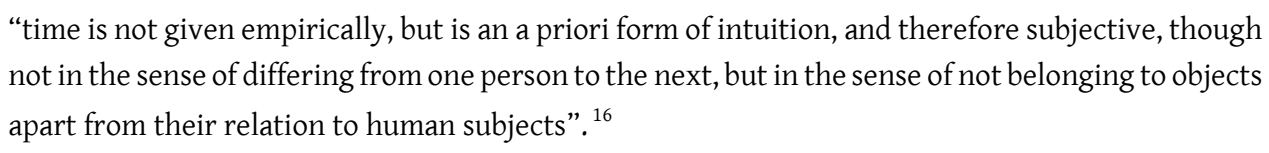

In fact, by claiming so, Kant seems to be in a struggle against relativism and subjective experience of time. In addition to this, Kant asserts that principles of relations of time or axioms of time in general 'could not be drawn from experience, for this would yield neither strict universality nor apodictic certainty'. ${ }^{17}$ In this context, what must be understood is apodictically that Kant seeks for the certainty and universality established by time as a subjective condition of intuition. Due to that time precedes all appearances of objects, and that the latter emerge under the conditions of the former, principles of time seem to have objective correctness and a priori universality. This is the reason why time cannot be applied to things in themselves. Time functions in a way that it is the condition of experience, and that it consists in itself all appearances.

What about alteration and motion? According to Kant, all concepts pertaining to sensibility, even that of motion, except time and space, presuppose the empirical. ${ }^{18}$ Alteration and motion necessarily occur under the condition of time and space respectively. Thus, time is not subject to alteration. Nonetheless, appearances can alter merely under the condition of time.

\section{Bergson's Understanding of Time}

Bergson's understanding of time is basically differentiated that of Kant in terms of having twodimensional structure as heterogenous duration and homogenous time. In Bergson's thought, there is an external reality which is given immediately to the mind, and which is mobility

$15 \quad$ Kant, Critique of Pure Reason, 178-179.

16 Helmut Holzhey - Vilem Murdoch, Historical Dictionary of Kant and Kantianism (Oxford: Scarecrow Press, 2005$), 266$.

$17 \quad$ Kant, Critique of Pure Reason, 179.

18 Kant, Critique of Pure Reason, 184. 
regarding changing states. ${ }^{19}$ Thus, their understandings of time, at the very beginning of our investigation of Bergson's approach to time, need to be considered as differentiated by means of their assumptions. We are well-aware of that Bergson accuses philosophical schools of placing themselves in analysis by means of which they have use of immobility of things to reach a solid, isolated, unchanging, and dull representation of reality, as if this is reality itself. The immobility of things is what our intelligence tends to follow because of some practical issues such as language, transmissibility, and daily life. Nonetheless, our intelligence, as Bergson denotes, 'can follow the opposite method. It can place itself within the mobile reality, and adopt its ceaselessly changing direction; in short, can grasp it by means of that intellectual sympathy which we call intuition'. ${ }^{20}$ While the former, as the use of intelligence to analyse, refers to immobility and dull representation of reality, thus, to existing or present science, metaphysics is clearly associated with intuition. ${ }^{21}$ Philosophers have generally followed the method of analysis; however, Bergson claims that, by means of intuition, science and metaphysics can come together. ${ }^{22}$ Hence, intuition is the central concept and method of Bergson's philosophy. His understanding of time is also very well-related to his concept of intuition. Intuition should be understood as the way through which each individual or, better to say, each consciousness-holder, encompassing simple substances too, reaches reality to the extent that its consciousness affords. In this way, each consciousness-holder experiences its individual duration and subsists in time to the extent it has something in common with others as consciousness-holders.

According to what Guerlac ${ }^{23}$ cites, 'William James admired Bergson's ability 'simply to break away from all old categories, deny old worn-out beliefs, and restate things ab initio, making the lines of division fall into entirely new places!" This could be taken similar to what is seen in Bergson's understanding of time. In his approach to time, he basically employs the displacement of old categories of time. In this context, Bergson propounds two kinds of time: homogeneous time and pure duration. He is in a struggle against stereotyped understanding of time compounded with that of space. As he clearly puts it,

"Now, let us notice that when we speak of time, we generally think of a homogeneous medium in which our conscious states are ranged alongside one another as in space, so as to form a discrete multiplicity. Would not time, thus understood, be to the multiplicity of our psychic states what intensity is to certain of them, - a sign, a symbol, absolutely distinct from duration? Let us ask consciousness to isolate itself from the external world, and by a vigorous effort of abstraction, to become itself again. We shall then put this question to it: does the multiplicity of our conscious

19 Henri Bergson, An Introduction to Metaphysics, trans. T. E. Hulme (New York: G. P. Putnam's Sons, 1912$), 65$.

$20 \quad$ Henri Bergson, An Introduction to Metaphysics, 69.

21 We have to note that Bergson's intuition contains in itself distinguishing feature compared to Kant's concept of intuition. Kant's intuition is mainly about getting representations of appearances, thus, sensibility. As Kant puts it, all direct or indirect thoughts must be related to intuitions. See Kant, Critique of Pure Reason, 155. However, forms of intuition, namely space and time, are not subjective in Kant's thought, even if time directly pertains to human beings. Furthermore, Bergson takes the concept of intuition both as a method to experience reality with the assistance of sympathy which derives from Ancient Greek, and means to be affected together, and as a subjective way of knowing. 'According to Bergson himself intuition is a sort of mental sympathy by means of which one may transfer himself into midst of an object'. See Bruno Jordan, "Kant and Bergson", The Monist 22/3 (1912), 406.

22 Bergson, An Introduction to Metaphysics, 74.

23 Suzanne Guerlac, Thinking in Time: An Introduction to Henri Bergson (New York: Cornell University Press, 2006$), 28$. 


\begin{abstract}
states bear the slightest resemblance to the multiplicity of the units of a number? Has true duration anything to do with space? Certainly, our analysis of the idea of number could not but make us doubt this analogy, to say no more. For if time, as the reflective consciousness represents it, is a medium in which our conscious states form a discrete series so as to admit of being counted, and if on the other hand our conception of number ends in spreading out in space everything which can be directly counted, it is to be presumed that time, understood in the sense of a medium in which we make distinctions and count, is nothing but space. That which goes to confirm this opinion is that we are compelled to borrow from space the images by which we describe what the reflective consciousness feels about time and even about succession; it follows that pure duration must be something different". ${ }^{24}$
\end{abstract}

Thus, time as homogeneous medium, as we have easily noticed, is nothing but compounding of what is individual with what belongs to space. In other words, pure duration as the novel discovery of Bergson, we prefer calling it discovery rather than invention due to its permanent subsistence somewhere in each consciousness-holder, is distinguished from homogeneous time regarding the similarity of the latter to space. What has been brought to be identical with space in the history of philosophy, in this sense, is nothing other than homogeneous time. On the one hand, homogeneous time is implicitly associated with space without even noticing this aspect as in the case of Kant's forms of sensible intuition; on the other hand, Bergson distinguishes it from pure duration of each consciousness-holder and puts it in the realm of mutual relations of consciousness-holders' pure durations. Obviously, it is quite reasonable to conceive of homogeneous time to be connected to space to the extent that their properties seem to be unfolded as they are similar to each other. ${ }^{25}$ In this sense, for Bergson, this kind of common point is the unifying ground of specific experiences of all consciousness-holders as it might be seen in language, science and so on. However, it is quite clear that pure duration cannot be taken as identical, or even similar, to space due to that main properties of space are simultaneity, infinity, divisibility, whilst pure duration excludes these and posits succession, finitude, and indivisibility. Bergson uses succession as indivisible and pure successiveness in pure duration. Pure duration, in this sense, is not the realm of quantity and measurability; rather, it has to be about quality and immeasurability of intensive experience of consciousness. As Bergson palpably depicts it,

"pure duration, that which consciousness perceives, must thus be reckoned among so-called intensive magnitudes, if intensities can be called magnitudes: strictly speaking, however, it is not a quantity, and as soon as we try to measure it, we unwittingly replace it by space" ${ }^{26}$

Thus, pure duration carries with itself neither simultaneity due to that it resembles a property of space, nor does it have quantity and measurability in itself. Then,

24 Henri Bergson, Time and Free Will: An Essay on the Immediate Data of Consciousness, trans. F. L. Pogson (New York: Dover Publications, 2001), 90-91.

25 Henri Bergson, Metafizik Dersleri: Uzay-Zaman-Madde, trans. B. Garen Beşiktaşlıyan (Istanbul: Pinhan Yayıncılık, 2014), 49.

26 Henri Bergson, Time and Free Will: An Essay on the Immediate Data of Consciousness, 106. 
"what is duration in us? A qualitative multiplicity, with no likeness to number; an organic evolution which is yet not an increasing quantity; a pure heterogeneity within which there are no distinct qualities. In a word, the moments of inner duration are not external to one another". ${ }^{27}$

This citation quite clearly tells us what Bergson means by speaking of the inner duration as pure duration. According to this very short paragraph, properties of pure duration are qualitative multiplicity, organic evolution, and heterogeneity, and, as a main property, succession. In this sense, moments of pure duration are melted down within each other. This seems to be what differs pure duration from homogeneous time. In other words,

"in consciousness we find states which succeed, without being distinguished from one another; and in space simultaneities which, without succeeding, are distinguished from one another, in the sense that one has ceased to exist when the other appears. Outside us, mutual externality without succession; within us, succession without mutual externality". ${ }^{28}$

In this context, pure duration is much more different than homogeneous time, and, thus, the idea that duration can be measurable is totally invalid. Rather than that, pure duration does not have the property of measurability. That should be understood as the result of its not having simultaneity. At the same time, pure duration has succession which does not involve distinguishing in itself. Otherwise, it would have divisibility through which the impossibility to move throughout a sequence became unveiled, and which each part had to remain confined in itself. Bergson notices that this is not the issue in consciousness possessing pure duration. Thus, moments of duration, as we have already mentioned above, intertwine, and successive moments of duration of each consciousness-holder are kept by memory. As Bergson clarifies, 'my mental state, as it advances on the road of time, is continually swelling with the duration which it accumulates: it goes on increasing - rolling upon itself, as a snowball on the snow. ${ }^{29}$ Memory accumulates the totality of indivisible succession unfolding itself in duration. This succession in duration is the experience of consciousness. In this sense, duration is limited to memory of the past, and to the prolongation of it into the present. Consequently, duration of each consciousnessholder is necessarily limited to its life. Hence, duration is unavoidably supposed to encompass the evolution and development of each consciousness. In other words, duration presents us a proceeding change and creativity, besides of memory. According to Bouton,

"for Bergson, duration, in all its forms, can be described in terms of three principal features, all of which arise out of psychological duration, which serves as the model: continual change, the automatic conservation of the past in memory, and creativity". ${ }^{30}$

Apparently, pure duration of any consciousness-holder unavoidably serve for creation by means of continual change durable. At the end of the day, duration refers to the possibility to get in touch with reality, that is, it does so by means of intuition. Since every movement is absolutely indivisible, and reality is mobility, the latter, as well as change, occurs in the realm of duration. ${ }^{31}$

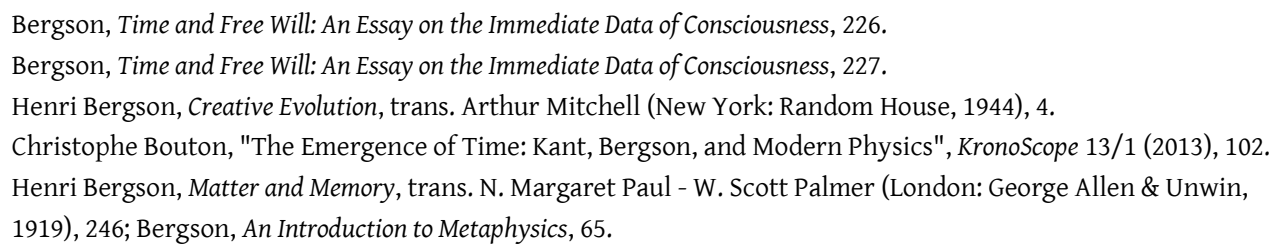


And, due to that duration contains this possibility, it is the main component of Bergson's understanding of time. Unlike homogeneous time, duration, in this context, presents us not dull appearance of object, but the continuous change and movement in reality, that is to say, it throws us into the midst of the object, rather than letting us perceive how the object is externally seen.

Unlike duration, homogeneous time comes into appearance as it is similar to space in terms of allowing things to be in a state of simultaneity or synchronicity. In this sense, it clearly implies extensity and measurability, thus, space. As a result, homogeneous time, as an impersonal consciousness distinguishing itself from individual consciousnesses which are found both in human beings and in other undeveloped and blurry substances by which Bergson means something similar to Leibniz's monads, but differed from them through the competence to have an impact on each other, is the ideal realm of what the mutual is in whole of individual durations. As Bergson clarifies to fortify his thought, this homogeneous time is impersonal consciousness, that is, space which is chosen as the expression of pure duration, or, which the points gradually moving away from each other represent the parts of duration symbolically. ${ }^{32}$ Thus, Bergson puts forward homogeneous time as degraded, secondary, and connective time, and, at the same time, impersonal consciousness. Bergson's thought is full of the concept of consciousness. What is important for us to notice is that, as Barnard perfectly puts it, 'in Bergson's vision of the universe, consciousness is not a mystery to be solved. Instead, consciousness is always present in the very heart of 'things". ${ }^{33}$

On the other hand, according to what we notice from Bergson's Time and Free Will, there should be two different selves: The fundamental self which is free, and its spatial and social representation which is basically amenable to measure due to being the external projection of $\mathrm{it}^{34}$. Thus, intuition is directly experienced by nothing but the fundamental self as the possessor of pure duration. In this context, getting to know externality clearly means that our consciousness attributes succession to things in simultaneity, or, in space. Besides this, as he puts it, "while our consciousness thus introduces succession into external things, inversely these things themselves externalize the successive moments of our inner duration in relation to one another' ${ }^{35}$ The relation of things occurs in space, or in homogeneous time, whilst succession and heterogeneity come into appearance in heterogeneous time, or in pure duration. And, through our consciousness we relate what is internal, indistinct, qualitative, mobile, successive, and heterogeneous to what is external, distinct, quantitative, or measurable, immobile, simultaneous, and homogeneous. This is, in its very concrete sense, the line in which pure duration and space, or homogeneous time, compromise.

Furthermore, Bergson grounds his understanding of time on his objection to Kant's understanding of time. According to Bergson, ${ }^{36}$

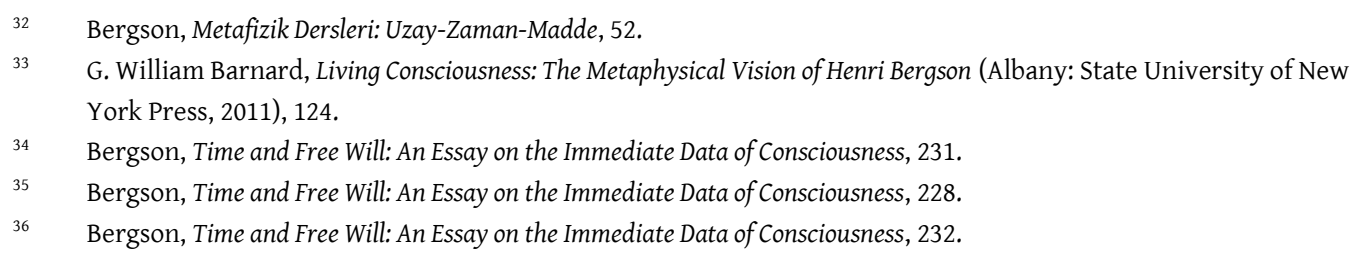


“Kant's great mistake was to take time as a homogeneous medium. He did not notice that real duration is made up of moments inside one another, and that when it seems to assume the form of a homogeneous whole, it is because it gets expressed in space. Thus the very distinction which he makes between space and time amounts at bottom to confusing time with space, and symbolical representation of the ego with the ego itself. He thought that consciousness was incapable of perceiving psychic states otherwise than by juxtaposition, forgetting that a medium in which these states are set side by side and distinguished from one another is of course space, and not duration".

By doing so, Kant unavoidably falls into the abyss of symbolical ego which cannot get in touch with the ego itself and is formed in space rather than in duration. What this does mean is that repetition of psychic states in consciousness is possible. In other words, causal relation occurring in space is internalised by Kant as a misunderstanding of duration as homogeneous time rather than heterogeneous one. That misunderstanding which constitutes juxtaposition of things or simultaneity in time, indeed, leads necessarily to banishment of the possibility of freedom from the self, and from the reach of our faculty of knowledge. Thus, freedom is imprisoned in unknowable sphere of noumena, or things in themselves. Thus, lack of freedom and artificially reconstructed self, or symbolical representation of the ego are the inevitable results of Kant's understanding of time.

As we have strived to write thoroughly above, Kant declares that time is one of the two forms of sensible intuition. By doing so, Kant clearly puts time in human beings and starts to centralise the subject as a reference point without falling into the abyss of relativity. He, at the same time, 'distinguishes the faculties by means of their relations to objects themselves. This leaves us with the difficult question of how to understand the opposition between things 'as they are' and 'as they appear" ${ }^{37}$ In fact, this is what internalisation of time serves for. At first glance, it seems to be the movement of relativism, or to serve for reconciliation between external and internal. However, then, it unfolds itself to be the annihilation of the part of things 'as they are' due to the fact that taking time and space as sensible intuition grounded in human being means nothing other than breaking up with externality and leaving totality of things to the mercy of human being as a species, thus, to the ideally based universality. Bergson, on the other hand, thinks of time much more individualised than Kant's understanding of time. Each consciousness, including both of human beings and undeveloped monad-like consciousnesses, has its own time as pure duration. In spite of that, he admits the existence of external reality. By doing so, he reasonably refrains from the rejection of what is outside of subject, and from falling into distraction in which the subject loses its specific and authentic state, thus, its subjectivity. In this context, Kant seems to teach Bergson what he must not do. The concept of intuition as it is taken by Bergson is the possibility of both experience of consciousness, and, thus, subjectivity of time, namely pure duration. On the other hand, the homogeneous time might refer to possibility of a unifying, Geistlike, and surrounding time. Now, we can retrace Iqbal's concept of time to find out inferences of Kant's and Bergson's understandings of time.

\section{Iqbal's Understanding and Use of Time}

37 Emily Carson, "Metaphysics, Mathematics and the Distinction Between the Sensible and the Intelligible in Kant's Inaugural Dissertation", Journal of the History of Philosophy 42/2 (2004), 177. 
When it comes to Iqbal's understanding of time which is parallel to his understanding of life in general, it is important to remark that he has a dynamic understanding of universe. He simply declares war against any kind of mechanism, and so, that of determinism. The roots of his freewillbased theory, which benefits much from his understanding of time as we will analyse below, is directly derived from this dynamical approach to universe. Even his epistemology is designed for this purpose, and he believes that intuition is an indispensable source for human knowledge as much as the reason and senses. With this inner source, Iqbal finds a significant explanation for the relationship between God and universe, and he also finds a space for freewill of human, and that of God. He asserts that the feeling (intuition) and the idea (thought) are the non-temporal and temporal aspects of the same unit of inner experience. By asserting so, he builds an organic link between the temporal and non-temporal through consciousness: The nature of the feeling seeks representation in thought. ${ }^{38}$

As the last step of our article, we will focus on the Iqbal's point of view and assert that he successfully benefited from Kant and Bergson, who have been aforementioned in this article, and that he adapted the understandings of time of those philosophers, especially the latter, to an Islamic stand with his own interpretations. To express this claim, we will separate our analysis into two headlines: What was Iqbal's approach about time? And how did he engage this approach with his theological and religious thoughts?

\subsection{Iqbal's Understanding of Time}

In Iqbal's thought, we witness two kinds of time as we have witnessed in that of Bergson: Serial time and pure duration. This separation has significant similarities with Bergson's homogenous time and heterogeneous time. The first and biggest similarity is that both are based on experiences of consciousness. As we have mentioned, Iqbal's understanding of inner experience has two sides: The idea which is related with sequential time; and the intuition, in which people get the chance to experience what is non-temporal. Intuition deals with pure time, since it extends with experience of consciousness and yet keeps being an indivisible whole in the sense of organic oneness of multitude. And what the idea does is to receive pure time in relation to successive moments and also in space, thereby it can put its sensation into words.

When Iqbal tries to understand time,${ }^{39}$ he also tries to find out a doubtless way of comprehension to use in his inquiry, that is, he hammers out, one's perception of his/her own-self. During his investigation, he points out two premises which are derived from one's own-self to reach one result that explains the relationship between consciousness and time: I change without ceasing. Constant change is unthinkable without time. Then, conscious existence means life in time. Hence, the unceasing change of the self constitutes the organic link between consciousness and time and leads up to the dynamic connection between what is internal and what is external. Subsequently, Iqbal takes forward this investigation on inner life of conscious experience and addresses two sides of the self: The appreciative side and the efficient side. This is kind of an

\footnotetext{
38 Muhammad Iqbal, The Reconstruction of Religious Thought in Islam (Stanford: Stanford University Press, 2013), 17.

39 Iqbal, The Reconstruction of Religious Thought in Islam, 37-38.
} 
adaptation and combination of Whitehead's Primordial Nature $e^{40}$ and Consequent Nature ${ }^{41}$ of God and Bergson's fundamental self and its spatial and social representation. Efficient Self, in other words the practical self, is related to space. It is considered as an outsider look and it lives in a time which can be described as short or long, that is, measurable, and perceived as a straight line, i.e., homogenous. But with a deeper investigation of conscious experience, he says, we will reach the Appreciative Self which lives in pure duration. This kind of time is like a single 'now' where there is no before and after. Appreciative Self changes and moves but still does not split up. By transforming the serial time of Efficient Self into one moment, Appreciative Self functions as the corrective of Efficient Self and synthesises all the 'heres' and 'nows' of the Efficient Self into the coherent wholeness of personality. ${ }^{42}$ In other words, Appreciative Self holds the unity of the ego by assembling the fragmental experiences of the Efficient Self. In this direction, Iqbal expresses this difference of self(s) as follows,

"Extensively regarded I am absorbed by the spatio-temporal order to which I belong. Intensively regarded I consider the same spatio-temporal order as a confronting 'other' wholly alien to me. I am distinct from and yet intimately related to that on which I depend for my life and sustenance". ${ }^{43}$

Thusly, we may also say that Efficient Self deals with the extensive and external dimensions of life, it is the self which nominalize the other, where Appreciative Self deals with the intensive and inner dimensions, and it is the self that is nominalized by the other. So far it looks very similar to Whitehead's natures and Bergson's egos and the latter's understanding of time.

But there is an important difference between Iqbal and Bergson, and also others. Bergson claims that pure duration of consciousness composes of past and present, where each past moment of homogenous time melts down in it as it always keeps being a unitary whole. There is no room for the future, in the sense of letting consciousness and the Reality be free and away from teleological determinations. But in Iqbal's point of view ${ }^{44}$ function of the consciousness is to provide a luminous point in order to enlighten the forward rush of life. It differentiates the organisms from machines by providing them the freewill with giving the opportunity to dynamically front the purposes which let pure duration to include the future as possibilities. The term of 'dynamic purpose' is a keyword for to understand his theory, because it is the concept that releases the idea of including the future in pure time of the consciousness from the imprisonment of the determinism. The dynamic purposes that shape the realm of the future do not draw a unique certain way to be followed; instead, they present the spectrum of the possible ways which may be followed.

"Pure time, then, as revealed by a deeper analysis of our conscious experience, is not a string of separate, reversible instants; it is an organic whole in which the past is not left behind, but is moving along with, and operating in, the present. And the future is given to it not as lying before,

40 It addresses God as the existence who organize the World. This nature is the precondition of to create. Everything is related to it.

41 It addresses God as in the flux of time. This nature is also unites with Primordial Nature eventually. It is related with everything.

42 Iqbal, The Reconstruction of Religious Thought in Islam, 39.

43 Iqbal, The Reconstruction of Religious Thought in Islam, 94.

44 Iqbal, The Reconstruction of Religious Thought in Islam, 33. 
yet to be traversed; it is given only in the sense that it is present in its nature as an open possibility". ${ }^{45}$

As it can be clearly understood from the phrase, Iqbal does not accept an understanding of purpose in the meaning of determination. On the contrary, as we have repeated many times to emphasize it, he strongly rejects the determined and mechanical understanding of life, similarly to Bergson. Yet, he also disagrees with Bergson about the behaviour of the Reality which is, as Bergson alleges, arbitrary, undirected, chaotic, and unforeseeable. ${ }^{46}$ According to Iqbal, when Bergson tries to escape from the necessitarian future of determinism, he hitches to the commotion of the nescience. Iqbal claims that ignoring the forward-looking aspect of the unity of consciousness is the biggest failure of Bergson. So that Iqbal propounds an alternative approach to teleology: Dynamic Purposes. Since life continuously expands, so does the mental life which accompanies it. Therefore, consciousness owns purposes and acts according to a teleological manner, but still is free and undetermined. 'To live is to shape and change ends and purposes and to be governed by them'. ${ }^{47}$ It is obvious that life and consciousness, and implicitly the purposes have an organic relation that they change all together according to one another. And it is also clear that Iqbal's understanding of the nature of Reality is teleological, in his own interpretation of teleology which does not obfuscate the freewill of the Reality. This teleology does not predict a certain future but presents future as open possibilities. One's for all, the process of time has a selective character.

The difference between Bergson and Iqbal by means of embracing the future in pure duration causes them to describe it with some different attributes. Bergson claims that pure duration is successive, even though he emphasizes the indivisible and aspatial nature of it. Since Bergson's pure duration excludes the future, it possesses succession on the contrary to simultaneity. On the other hand, Iqbal strictly isolates pure duration of the consciousness from succession since it contains past, now, and future as a whole without ordering any of them. Accordingly, one might say that Iqbal's understanding of time reveals integrity even more than that of Bergson.

\subsection{Iqbal's Understanding of Divine Time and Destiny: The Reconstruction of Freewill}

What we have discussed about Iqbal's understanding of time brings us to the question of what whips in all the single and 'separated' durations of the 'different' consciousnesses. His answer to our question is hidden in the notion of Ultimate Reality.

\footnotetext{
"Neither pure space nor pure time can hold together the multiplicity of objects and events. It is the appreciative act of an Enduring Self only which can seize the multiplicity of duration -broken up into an infinity of instants- and transform it to the organic wholeness of a synthesis". ${ }^{48}$
}

In Bergson's view, homogenous time as an impersonal consciousness was the symbolic holder of collectiveness of the duration of each consciousness. But in Iqbal's view, as we have seen, it is another duration, which is assembling but also still indivisible, of another Self, that is, the

45 Iqbal, The Reconstruction of Religious Thought in Islam, 39-40.

46 Iqbal, The Reconstruction of Religious Thought in Islam, 42.

47 Iqbal, The Reconstruction of Religious Thought in Islam, 43.

48 Iqbal, The Reconstruction of Religious Thought in Islam, 44-45. 
Ultimate Reality. The duration and the Self that are mentioned here represent the most inclusive Self and duration, which are named by Iqbal as the Ultimate Ego and Divine Time. To put it differently, we can say that the impersonal consciousness in Bergson's theory becomes personal in Iqbal's thought.

When we take a closer look at Divine Time, it is indivisible, unchanging, and innumerable. It is even more superior to eternity since it does not have any beginning or ending. Allah sees and hears all events in a single act of perception. It is described in Qur' an as 'Umm al-Kitāb' which means 'the Mother of the Books'. It corresponds to the history as a whole that is freed from the causal sequences, and it is gathered up in a single super-eternal 'now'. ${ }^{49}$ Thus, Ultimate Ego possesses change without succession as an organic wholeness. We, as human beings, perceive it in an atomic manner because of the creative action of the Ultimate Ego.

\footnotetext{
"Personally, I am inclined to think that time is an essential element in Reality. But real time is not serial time to which the distinction of past, present, and future is essential; it is pure duration, i.e. change without succession, which McTaggart's argument does not touch. Serial time is pure duration pulverized by thought - a kind of device by which Reality exposes its ceaseless creative activity to quantitative measurement". ${ }^{50}$
}

Here, the serial time looks similar to Kant's understanding of time as one of the two forms or preconditions of sensible intuition. It is like a filter of the mind to perceive and verbalise the pure duration by dividing it into spatio-temporal particulars. However in Iqbal's system of thought, serial time is only applied for the idea, one of the two units of inner experience, which is related with space and language. On the other hand, the second unit of inner experience, namely the intuition, pulls together with the pure duration, which is similar with Bergson's understanding. But it is important to notice that we have talked about the pure duration in two senses, pure duration of egos and that of the Ultimate Ego. To understand how similar and different those two senses are, we need to underline Iqbal's closeness to the mystic thoughts, especially to Wahdat alWujū $d .^{51}$ The condition for the existence of the self in pure duration is to be able to say 'I am' which is based on the distinction from not-self. But for the Ultimate Self, there is no not-self which presents itself as a confronting 'other'. ${ }^{52}$ So, the meaning of pure duration in Bergson and Iqbal either in the sense of ego or the Ultimate Ego are actually still the same. Nevertheless, when it comes to the Ultimate Ego, what changes is the nature of the Self, rather than the time. Iqbal claims that the notion of matter is not something that is co-eternal with God and operated upon by Him from a distance as it were. The Ultimate Ego has only, in its real nature, one continuous act that is broken up into a plurality of mutually exclusive things by the thought. ${ }^{53}$

Last but not least, we have to mention what does the Divine Time says about the destiny and freewill. Iqbal determines the destiny ${ }^{54}$ ( $q a d r$ ) as the time that is regarded as prior to the disclosure of its possibilities, and he complains about misunderstanding of the issue in Islamic world. Some

Iqbal, The Reconstruction of Religious Thought in Islam, 60-61.

Iqbal, The Reconstruction of Religious Thought in Islam, 46-47.

A Sufi term that indicates the oneness of the existence and the oneness in the existence.

Iqbal, The Reconstruction of Religious Thought in Islam, 45.

Iqbal, The Reconstruction of Religious Thought in Islam, 53.

Iqbal, The Reconstruction of Religious Thought in Islam, 40. 
of the Muslim scholars defended the deterministic approach to human life to render the Omnipotence and Omniscience of Allah, and some others wiped any slightest knowledge about the future out of the table to ensure God's Justice. Iqbal asks the question of why two known characters of the world history lived in the same period of time. Here, his definition of destiny gets clearer: It is the enabler characteristic of the Reality among the infinitive possibilities. His understanding of destiny is independent from causality and, of course, determinism; instead, it is the encompassing set of possibilities in which events may occur. What determines the pattern to follow between those possibilities is nothing other than freewill of God and, as we will see, that of human. Because, he says, every moment of the Reality should be and is original. To ensure that, he points out the difference between creation and repetition. Repetition pertains to mechanical actions, whereas creation is a dynamic, so that, free and unpredictable action. God does not repeat, He is beyond all the determinisms and mechanisms; on the contrary, He creates as the original source of all beings with the perfect power of appointment, i.e., His Divine Will. While Iqbal makes room for the Divine Will, he does not deny freewill of humans. On the contrary, Iqbal even expresses that Islamic scholars should not be afraid of the limitation of God when He chooses to limit himself with His own Divine Will. Iqbal claims that God gives humans freewill to choose between possibilities and to tend towards them, and he also thinks that it is not a limitation at all when He is the one who chooses to do so. As a reminder, pure duration of consciousness includes future with dynamic purposes. These dynamic purposes of egos are where Iqbal paves the way for humans' freewill. Willing a purpose and heading for it, which mean determining the future realm of one's pure duration, are in the list of competences of one's freewill given by God. At this point, we see some similarities with the notion of al-irāda al-juz'iyya ${ }^{55}$ in classical Islamic theology, especially in Māturīiryya. ${ }^{56}$

So far, we have tried to explain what Iqbal propounds about time and how he uses it in a religious aspect to reconstruct the concept of freewill. We have clearly seen that there are two kinds of time in Iqbal's system. Serial time as a linear structure that is used by the idea which is one of the two units of inner experience; and pure duration as only one moment that is the organic wholeness of the past, now, and future, used by intuition which is the second unit. As it is understood, the definitions of times depend on inner experience; Iqbal discusses time in a matter of own-self. They both belong to different units of the self. He even named these units: Appreciative Self and Efficient Self. This self-centred approach to time is directly reminds us Kant's subject-centred concept of time. But with a further reading, it is understood that what is similar with Kant's understanding is only the serial time. In Iqbal's system, serial time is not the real time; it partitions the pure duration to serve for the perception of the idea which is related with spatio-temporal order. When it comes to pure duration, it is much more similar with Bergson's heterogeneous time, which he also calls as pure duration. Both the heterogeneous time of Bergson and pure duration of Iqbal expand with each moment that joins them, but also every moment that joins them becomes an impartible part of the whole. In the end, pure duration keeps

55 A theory about human act's and freewill. It express human's roll in his/her actions in the sense of being free and selector by tending towards it.

56 One of the main schools of Sunnī theology (Ahl al-Sunna wa al-Jamāa $a$ ) in Islam. It was built by Abū Ḥanīfa and Abū Manșūr al-Māaturīdī. 
being a single 'now' no matter how much it expanded. On the other hand, Bergson's pure duration consists of past and present and excludes future, with the intent of drawing an undetermined future and ensuring the freedom of the consciousness. Iqbal, contrarily, thinks that pure duration includes future as much as the past and present. He believes that a dynamical understanding of the universe can be also applied to the teleology, and that a dynamic teleology outlines not chaotic but a perfectly free universe. What dynamic teleology says about future is not a predicted story; rather than that, it is all about open possibilities. This is directly related with Iqbal's understanding of destiny which is also a disclosure of open possibilities. Here, one is free to tend any of the possible futures that are presented to him/her. Now, we have a better understanding of what Iqbal strived to do with his work. He simply paved the way for freewill of humans which has been a very discussed issue in Islam in particular, and in the history of thought in general. God encompasses the entire universe; He as the Ultimate Self perceives everything in one moment of time since all time is just a moment to him in the sense of duration. He enables humans' freedom without compromising on His omnipotence.

\section{In Lieu of Conclusion}

Throughout this article, we have witnessed Kant's, Bergson's, and Iqbal's understandings of time. Kant's time is shaped as it is the form of sensible intuition rooted in the subject; however, it cannot be claimed that Kant's time is subjective. Besides this, his time is also homogeneous, and, thus, as we have seen above, does not allow freedom to come into appearance. Consequently, according to Bergson, Kantian conceptualisation of time has to tangle time with space, and the ego with the symbolical representation of ego. ${ }^{57}$ In this context, Bergson asserts two kinds of time, namely homogeneous time and pure duration. On the other hand, even though Bergson criticises Kant, he seizes Kant's time to establish externality and space as the realm of simultaneity. By doing so, he assures us that commonalities of consciousnesses are represented by this kind of time, namely homogeneous time, which is measurable, divisible, and involves simultaneity. Thus, consciousnesses are not unaware of each other, and, they have a solid and common ground by homogeneous time, i.e., language by means of which representations of things come into view and establish a communal realm. For, without this, each consciousness has to be confined in its own. Homogeneous time, in this sense, refers to superficiality to understand the universe and self. Unlike it, heterogeneous time, or better, pure duration, implies inner sense as a realm of intuition and self-realising or self-understanding. Thus, intuition cannot easily find voice in language. However, pure duration is, at the same time, the realm of freewill. Unlike Kant's time, it has neither repetition nor causal relations in itself.

Iqbal takes Kant's time as serial time similar to Bergson's homogeneous time. This conception of time is based on divisibility. Like Bergson and Kant, Iqbal means possibility of commonalities of consciousnesses, simultaneity, and space by the concept of serial time. On the other hand, he conceptualises pure duration. All egos and God as the Ultimate Ego experience this pure duration. At this point, what reveals itself to us is that the Ultimate Ego's pure duration has to embrace all other egos' pure duration. In this context, the Divine Time as the pure duration of the Ultimate

57 Bergson, Time and Free Will: An Essay on the Immediate Data of Consciousness, 232. 
Ego holds together all events. It encompasses all possibilities which might occur at any time. In this sense, the Divine Time is unchanging due to that it has all possibilities in itself. In addition to this, the Ultimate Ego experiencing the Divine Time is nothing other than the God. However, it is crucial to denote that the Divine Time is not mixed up with serial time. All other egos can relate to each other through space, and, thus, through serial time as the divisible time by means of which the thought or inner sense can interact with that of other egos. The God is omnipresent, and, thus, cannot be limited to space as simultaneity, or, to a limited and divisible time. Therefore, the Divine Time as the God's duration cannot be limited to being in serial time.

Homogeneous time, or serial time in Iqbal's thought, does, of necessity, presupposes causality and repetition. Homogeneity recurs what it has in itself. Thus, it is theoretically impossible to think of freewill in serial time. Freewill can only be found in pure duration in which repetition and causality are excluded. This basically means that creativity must continue to be in pure duration. As we have clearly spoken of it, the Divine Time should be realised as the God's experience of duration, that is to say, it covers other egos' durations. Hence, the Ultimate Ego and other egos have freewill.

The Ultimate Ego surrounds the universe and is in it. 'The universe is, ..., 'the behaviour of God". ${ }^{58}$ By claiming so, Iqbal denotes that the God is not separated from the universe and does not have its absolute closedness in terms of that $\mathrm{He}$ is no more related to the universe. Rather than this, $\mathrm{He}$ always relates Himself to the universe and He has chosen to give other egos the right to choose, which is nothing other than freewill. His choice of giving other egos freewill is not a deficiency and does not make Him finite; it is nothing but the power of the Ultimate Ego. ${ }^{59}$ This is what Iqbal's investigation of time results in. It refers to the reconstruction of Islamic thought encompassing freewill of each ego as consciousness experiencing duration.

By his endeavour to reconstruct the theory of freewill in Islamic thought, Iqbal brings in two new approaches to the understanding of time. One of them is that Iqbal develops a dynamic understanding of teleology to be applied to his understanding of destiny which constitutes the main basis of the concept of freewill. In other words, he accepts an understanding of teleology which differs from its permanent and solid representation as the implementation of givenness. Iqbal's teleology is shaped by humans' freewill which dynamically and continuously turns towards possibilities. By doing so, teleology is detached from being imposed to the nature of things and turned into a compatible concept with Iqbal's organic and dynamic system of thought. This new approach to teleology based on dynamic purposes rather than dull purposes paves the way for Iqbal's second original contribution to the concept of time, thus, that of freewill. Iqbal deploys the future in pure duration as an addition to Bergson's understanding of pure duration which solely includes one's past and present. Iqbal believes that consciousness-holders are not total strangers to their futures. On the contrary, they do have plans, dreams, and purposes which play an effective role to form their futures. Hence, Iqbal's pure duration, unlike that of Bergson, does not constitute a chaotic future in order to open a room for humans' freewill. Iqbal's dynamic future occurs in the

\footnotetext{
58 Mehmet Aydın, "Iqbal's View of God's Infinity", Dokuz Eylül Üniversitesi Ilahiyat Fakültesi Dergisi 2 (1985), 4.

59 Kasım Küçükalp, "Süreç Teolojisi ve Muhammed İkbal", Hece 193 (2013), 309.
} 
possibilities embraced by the omniscience of the Ultimate Ego, and is shaped by the freewill of humans which is also given by the Ultimate Ego Himself.

With the concept of freewill, Iqbal founds a correspondent relationship between modern philosophy and Islamic thought. Iqbal's intervention shaped by his concept of freewill based on his understanding of time might be understood as a reformative and transformative potential in Islamic thought. It also unveils very potential of Islam to reply to the problem of freedom, and the need and questions of emancipation in modern times. The reason for the success of Iqbal's concept of freewill in order to have potential to be transformative lies down beneath its formulation process affected by modern and contemporary Western philosophy, Islamic thought, and also mysticism. And much more attempts and enthusiasm to develop Iqbal's concepts of time and freewill are needed to reply to novel questions arisen in $21^{\text {st }}$ century. 


\section{Bibliography}

Aydın, Mehmet. 'Iqbal's View of God's Infinity'. Dokuz Eylül Üniversitesi İlahiyat Fakültesi Dergisi 2 (1985), 1-8.

Barnard, G. William. Living Consciousness: The Metaphysical Vision of Henri Bergson. Albany: State University of New York Press, 2011.

Bergson, Henri. An Introduction to Metaphysics. trans. T. E. Hulme. New York: G. P. Putnam's Sons, 1912.

Bergson, Henri. Creative Evolution. trans. Arthur Mitchell. New York: Random House, 1944.

Bergson, Henri. Matter and Memory. trans. N. Margaret Paul - W. Scott Palmer. London: George Allen \& Unwin, 1919.

Bergson, Henri. Metafizik Dersleri: Uzay-Zaman-Madde. trans. B. Garen Beşiktaşliyan. Istanbul: Pinhan Yayıncılık, 2014.

Bergson, Henri. Time and Free Will: An Essay on the Immediate Data of Consciousness. trans. F. L. Pogson. New York: Dover Publications, 2001.

Bouton, Christophe. 'The Emergence of Time: Kant, Bergson, and Modern Physics'. KronoScope 13/1 (2013), 96-111. brill.com/kron

Carson, Emily. 'Metaphysics, Mathematics and the Distinction Between the Sensible and the Intelligible in Kant's Inaugural Dissertation'. Journal of the History of Philosophy 42/2 (2004), 165194.

Caygill, Howard. A Kant Dictionary. Oxford: Blackwell Publishing, 2009.

Diagne, Souleymane Bachir. 'Bergson in the Colony: Intuition and Duration in the Thought of Senghor and Iqbal'. Qui Parle 17/1 (2008), 125-145.

Gözkân, H. Bülent. Kant'ın Şemsiyesi - Kant'ın Teorik Felsefesi Üzerine Yazılar. Istanbul: Yapı Kredi Yayınları, 2018.

Guerlac, Suzanne. Thinking in Time: An Introduction to Henri Bergson. New York: Cornell University Press, 2006.

Hassan, Riffat. The Main Philosophical Idea in the Writings of Muhammad Iqbal (1877-1938). Durham: Durham University, Doctoral Thesis, 1968. http://etheses.dur.ac.uk/7986/

Hassan, Riffat. 'The Meaning and Role of Intuition in Iqbal's Philosophy'. Iqbal Review 26/1 (1985), $67-99$.

Heimsoeth, Heinz. Kant’’n Felsefesi. trans. Takiyettin Mengüşoğlu. Ankara: Doğu Batı Yayınları, 2012.

Holzhey, Helmut - Mudroch, Vilem. Historical Dictionary of Kant and Kantianism. Oxford: Scarecrow Press, 2005. 
Iqbal, Muhammad. The Reconstruction of Religious Thought in Islam. Stanford: Stanford University Press, 2013.

Jordan, Bruno. 'Kant and Bergson'. The Monist 22/3 (1912), 404-414. http://www.jstor.com/stable/27900386

Kant, Immanuel. 'Concerning the Ultimate Ground of the Differentiation of Directions in Space'. trans. David Walford - Ralf Meerbote. Theoretical Philosophy, 1755-1770. 361-372. New York: Cambridge University Press, 1992.

Kant, Immanuel. Critique of Pure Reason. trans. Paul Guyer - Allen W. Wood. New York: Cambridge University Press, 1998.

Kant, Immanuel. 'On the Form and Principles of the Sensible and the Intelligible World [Inaugural Dissertation]'. trans. David Walford - Ralf Meerbote. Theoretical Philosophy, 1755-1770. 373-416. New York: Cambridge University Press, 1992.

Kant, Immanuel. Universal Natural History and Theory of the Heavens. trans. Ian Johnston. Arlington: Richer Resources Publication, 2008.

Küçükalp, Kasım. ‘Süreç Teolojisi ve Muhammed İkbal'. Hece 193 (2013), 302-309.

Mohomed, Carimo. "'The Days of God"- Muhammad Iqbal's Conception of Time and History'. Journal of Islamic Thought and Civilization 7/ (2017), 1-17. https://doi.org/10.29145/2017/jitc/72/070201

Mohomed, Carimo. 'Towards a Final Combination - Muhammad Iqbal's Philosophy of History'. Journal of Philosophy and Ethics 2/1 (2020), 17-31.

Mohomed, Carimo. 'Towards a Final Combination: Muhammad Iqbal's Philosophy of History'. Waikato Islamic Studies Review 6/2 (2020), 21-35.

Popp, Stephan. 'Muhammad Iqbal - Reconstructing Islam along Occidental Lines of Thought'. Interdisciplinary Journal for Religion and Transformation in Contemporary Society 5/ (2019), 201-229.

Raju, P. T. Idealistic Thought of India. London: George Allen \& Unwin, 1953.

Shabel, Lisa. 'The Transcendental Aesthetic'. The Cambridge Companion to Kant's Critique of Pure Reason. ed. Paul Guyer. 93-117. New York: Cambridge University Press, 2010.

Wheeler, Richard S. 'The Individual and Action in the Thought of Iqbal'. The Muslim World 52/3 (1962), 197-206. 